\title{
PENGARUH PROMOSI TERHADAP EFEKTIVITAS KERJA KARYAWAN PADA PT. KARYA NIAGA DI BANDAR LAMPUNG
}

\author{
Nuzleha $^{1}$, Yuliana Yamin ${ }^{2}$, Novalia ${ }^{3}$ \\ Universitas Sang Bumi Ruwa Jurai \\ nuzlehahadjar1970@gmail.com¹, yulianayamin0607@gmail.com², \\ novaliasholehah@gmail.com ${ }^{3}$
}

\begin{abstract}
ABSTRAK
PT. Karya Niaga di Bandar Lampung adalah perusahaan perdagangan lampu philips, dihadapkan pada masalah persaingan dalam pemasarannya dengan usaha sejenisnya. Oleh karena itu harus mendapatkan perhatian dan diberikan informasi atau promosi mengenai perkembangan produk harga maupun mutu dan pelayanannya, sehingga diharapkan efektivitas kerja karyawan yang tinggi dalam penjualan menjadi stabil bahkan meningkat. Tujuan dari penelitian ini adalah untuk mengetahui pengaruh promosi terhadap efektivitas kerja karyawan pada PT. Karya Niaga di Bandar Lampung. Hipotesis yang diajukan dalam penelitian ini adalah: "Ada Pengaruh Promosi Terhadap Efektivitas Kerja Karyawan Pada PT. Karya Niaga di Bandar Lampung". Pengambilan sampel menggunakan teknik sampel deret waktu $(\mathrm{n}=10)$. Metode penelitian yang digunakan analisis kualitatif dan kuantitatif digunakan adalah regresi linier sederhana. Hasil analisis diperoleh persamaan bahwa : $\mathrm{Y}=-50,51+22,37 \mathrm{X}$. Hasil pengujian menggunakan rumus $t$ student, menunjukkan bahwa t hitung 19,85 $>\mathrm{t}$ tabel 2,828, berarti Ho ditolak dan Ha diterima. Dengan demikian hipotesis yang diajukan: "ada pengaruh promosi terhadap efektivitas kerja karyawan pada PT. Karya Niaga di Bandar Lampung", diterima.
\end{abstract}

Kata Kunci: promosi, efektivitas kerja karyawan

\section{ABSTRACT}

PT. Karya Niaga in bandar lampung is a mercantile company a lamp philips, well in the face of the problem of competition in the omnipresence with effort the like. For that reason it is has to do to get attention and is given information or promotion on the development of the product the price of and in quality and the services, so it was expected that the effectiveness of the employees who high in the sale of become remain stable as the rate increase from time to time. The purpose of this study is to find the influence of campaign to promote bos program best work inside the box he would do to pt on the effectiveness of tens of thousands of workers. The work of niaga in Bandar Lampung .Hypothesis advanced by in this research was: "there an effect on the effectiveness of employees can be transferred to a great contribution to the best work inside the box he would do to PT. The work of niaga in bandar lampung”. The sample sample the time using a technique $(n=10)$. Research methodology used the qualitative and quantitative analysis simple used is linear regression. The results of the analysis of that: he obtained $=-50,51+x 22,37$. Receive true any impact on the effectiveness of promotion positive work an employee at PT. Trade work in Bandar Lampung. The testing using formulas $t$ student, shows that t count 19,85 gt \& table 2,828, $t$; means ho ha rejected and received. Thus hypothesis submitted: "promotion work any impact on the effectiveness of an employee at PT. Trade work in Bandar Lampung ", received.

Keywords: promotion, the effectiveness of work employees 


\section{PENDAHULUAN}

Pemasaran merupakan suatu kegiatan mempengaruhi konsumen untuk bersedia membeli, menggunakan barang atau jasa suatu perusahaan pada saat mereka membutuhkan, kebijaksanaannya harus diperhitungkan mengenai kemampuan sumber daya manusia, promosi dan biaya produksi secara terperinci, lengkap, akurat dan tepat.

Kondisi pasar yang kompleks dan banyak terdapat perusahaan bergerak dalam bidang yang sama, maka akan dapat menimbulkan persaingan, sehingga sulit untuk meningkatkan penjualan sesuai dengan rencana target ditetapkan, dilain pihak, konsumen juga menjadi lebih selektif untuk memilih produk yang dianggapnya dapat memberikan kepuasan diantara beberapa alternatif pilihan.

\section{Upaya}

dan mengatasi kendala tersebut diatas, diperlukan pengelolaan dan pengkoordinasian mencakup perencanaan produk disesuaikan kebutuhan konsumen, pengembangan produk, penetapanharga, pendistribusian dan promosi yang baik, keempat unsur kegiatan itu saling berhubungan disebut dengan bauran pemasaran. Sebagai dasar pertimbangan selanjutnya, agar kegiatan - kegiatan perusahaan dapat mengarah pada tujuan perlu diadakan evaluasi. Sesuai pendapat Philip Kotler, (2012 : 18) "Bauran pemasaran adalah seperangkat alat pemasaran yang digunakan oleh perusahaan untuk mencapai tujuan pemasarannya".

Perusahaan yang berorientasi memenuhi keinginan konsumen, harus menentukan kebutuhan pokok dari pembeli untuk dilayani, memilih sasaran dalam penjualan, menentukan produk dan program pemasaran, menitik beratkan pada mutu tinggi, harga murah atau desain menarik. Pengertian tersebut memberikan suatu gambaran penting, memuaskan kebutuhan dan keinginan konsumen melalui proses pertukaran.

PT. Karya Niaga di Bandar Lampung bergerak di bidang perdagangan lampu merk philips dengan jenis, antara lain ; Superlux, Luxram, Elektolux, Elektric LED. Sumber pendapatan perusahaan ini adalah laba dari kegiatan penjualan, oleh karena itu diperlukan upaya untuk dapat membujuk secara aktif para konsumen, agar tertarik untuk segera memenuhi dan menyelesaikannya dengan cara membeli.

Perusahaan sering mengalami kendala dalam memasarkan produk lampu philips karena banyak pesaing yang memasarkan produk lampu sejenisnya, seperti ; luxram, Ebasco, Amasco, Pioline, dllnya, dengan harga relatif lebih murah. Maka pihak manajemen PT. Karya Niaga di Bandar Lampung berupaya mengatasi persoalan tersebut dengan cara menerapkan bauran pemasaran salah satunya mempromosikan produk melalui media cetak (koran, majalah, brosur, dll) dan elektronik (website, radio, televisi), serta memberikan potongan harga atau jaminan kualitas barang.

Berdasarkan fenomena di atas, maka penulis tertarik untuk menelitinya lebih lanjut dengan judul; "Pengaruh Promosi Terhadap Efektivitas Kerja 
Karyawan Pada PT. Karya Niaga di Bandar Lampung,".

\section{KAJIAN TEORI}

\section{Pengertian Pemasaran}

Pemasaran adalah suatu sistem keseluruhan dari kegiatankegiatan bisnis yang ditujukan untuk merencanakan, menentukan harga, mempromosikan, dan mendistribusikan barang dan jasa yang memuaskan kebutuhan baik kepada pembeli yang ada maupun pembeli potensial. (Swastha DH, Basu, 2012 : 72).

Menurut Philip Kotler, (2012 : 18) "bauran pemasaran (marketing mix), adalah seperangkat alat pemasaran, produk (product), harga (price), tempat atau distribusi (place), promosi (promotion) yang digunakan oleh perusahaan untuk mencapai tujuan pemasarannya"

Dalam pemasaran diperlukan manajemen yaitu; proses perencanaan dan pelaksanaan konsepsi, penetapan harga, promosi dan distribusi gagasan pada barang dan jasa untuk menghasilkan pertukaran yang memenuhi sasaransasaran perorangan dan organisasi.

Dalam memasarkan produk terdapat kendala yakni persaingan antara perusahaan dimana dapat dibedakan dalam empat tingkat berdasarkan tingkat substitusi produk :

\section{Persaingan merk}

Perusahaan dapat melihat para pesaingnya sebagai perusahaan lain yang menawarkan produk dan jasa sejenis kepada pelanggan yang sama dengan harga yang sama.

2. Persaingan Industri
Perusahaan dapat memandang pesaingnya secara lebih luas sebagai perusahaan yang membuat produk atau jenis produk yang sama.

3. Persaingan bentuk

Perusahaan dapat memandang pesaingnya secara luas sebagai semua perusahaan membuat produk yang memberikan jasa yang sama.

4. Persaingan Umum

Perusahaan dapat memandang pesaingnya secara lebih luas sebagai semua perusahaan yang besaing untuk consumer rupiah yang sama.

( Swastha DH, Basu, 2012 : 69)

\section{Pengertian Promosi}

Promosi merupakan salah satu variabel di dalam marketing mix, yang perlu dilaksanakan oleh perusaahaan dalam rangka pemaran barng atau jasa. Kegiatan promosi erat hubungannya dengan usaha dari suatu perusahaan dalam rangka memasarakan produk yang dihasilkan dengan harapan agar dapat dicapai tingkat volume penjualan tertentu dan dapat memberikan keuntungan yang diharapkan.

Promosi adalah arus informasi atau persuasi satu arah yang dibuat untuk mengarahkan seseorang atau organisasi kepada tindakan yang menciptakan pertukaran dalam pemasaran. Oleh karena itu promosi yang dilaksanakan oleh perusahaan dapat diarahkan untuk mempengaruhi tingkat pengetahuan sikap pembeli, agar bersedia membeli barang dan jasa yang ditawarkan, apabila suatu usaha kombinasi yang terarah dan pemakaian elemen yang tepat.

Promosi dipengaruhi oleh faktorfaktor ; besarnya dana yang digunakan 
untuk promosi, Sifat pasar, Jenis produk yang dipromosikan, tahap-tahap dalam siklus kehidupan barang. (Swastha DH, Basu, 2012 : 92 ).

\section{Kegiatan dan Tujuan Promosi}

Kegiatan promosi adalah suatu usaha yang dilakukan penjual untuk memperkenalkan produk kepada calon konsumen dan membujuk mereka agar membeli, serta mengingatkan kembali konsumen lama agar melakukan pembeli ulang. (J.William dkk, 2012 : 98 )

Pemasaran pada saat ini tidak cukup hanya dengan pengembangan produk, peningkatan kualitas, penetapan harga terjangkau atau penyaluran produk yang tepat. Tetapi terlebih lagi produsen harus dapat berkomunikasi dengan langganannya. Hal ini bisa dilakukan misalnya dengan promosi, pengiklanan atau dengan melatih para tenaga penjual, agar dapat menyampaikan pesan produsen tentang produk yang dijualnya. Promosi mencakup semua kegiatan perusahaan untuk memperkenalkan produk dan bertujuan agar konsumen tertarik untuk membelinya. Bila perlu dengan cara membujuk konsumen dalam melakukan transaksi pembelian produk.

Untuk mengetahui perilaku konsumen dalam melakukan pembelian dipengaruhi baik oleh emosinya maupun oleh akal sehatnya. Pengaruh emosi disini misalnya, seseorang melakukan pembelian hanya karena ingin disebut tidak ketinggalan mode, merasa bangga agar supaya nampak esklusif. Sedangkan faktor ekonomis atau akal sehat dapat pula merupakan faktor yang mendorong pembelian, misalnya konsumen sebelum melakukan pembelian dengan membandingkan dulu mengenai harga, kualitas, servis yang mudah dan lain-lainnya.

Untuk itu diperlukan rencana untuk mencapai tujuan program penjualan atau faktor yang mempengaruhi strategi promosi diantaranya :

1. Periklanan (Advertising)

Bentuk penyajian dan promosi bukan pribadi (non personal) yang diselenggarakan melalui media bayaran mengenai produk / jasa gagasan sponsor tertentu yang nyata. Dengan periklanan, perusahaan berharap dapat membangun citra produk dalam jangka panjang. Periklanan sangatlah luas jangkauannya, karena dengan dimuat dalam media cetak, elektonik, brosur edaran, spanduk, papan reklame dan lain-lain.

2. Penjualan Pribadi (Personal Selling) Dengan penjualan pribadi maka akan terciptakan suatu interaksi langsung antara pembeli dan penjual, sehingga penjual akan segera mengetahui reaksi pembeli mengenai produk. Hanya saja diperlukan tenaga penjual yang baik serta biaya yang cukup besar dibandingkan dengan jenis media promosi.

3. Promosi Penjualan (Sales Promotion) Jenis promosi banyak disukai penggunanya oleh perusahaan karena, memiliki sifat yang komunikatif serta mengundang konsumen untuk membeli saat itu pula. Promosi penjualan juga dapat menciptakan tanggapan yang lebih kuat dan lebih cepat. Biasanya kegiatan promosi 
penjualan dijalankan bersama-sama kegiatan promosi lainnya.Misalnya kegiatan promosi penjualan dengan: pameran, demontrasi, pertunjukan, peragaan.

4. Publisitas (Publicity)

Publisitas memiliki daya tarik tertentu yaitu dapat menimbulkan kepercayaan yang tinggi .Publisitas berusaha menciptakan hubungan yang menguntungkan antara perusahaan dengan masyarakat. Oleh karena itu publisitas juga merupakan bagian dari kegiatan hubungan masyarakat dari suatu perusahaan. (Murti Sumarni, 2012 : 96).

\section{Pengertian Efektivitas Kerja}

Setiap organisasi akan selalu berusaha semaksimal mungkin melaksanakan tugas dan pokoknya dalam pencapaian tujuan yang telah ditetapkan. Oleh karena itu selayaknya organisasi selalu mengupayakan dan memelihara efektivitas kerja karyawan yang tinggi. Efektivitas pemanfaatan sumber daya, sarana dan prasarana dalam jumlah tertentu yang secara sadar ditetapkan sebelumnya untuk menghasilkan sejumlah barang atau jasa kegiatan yang dijalankan (Sondang P. Siagian, 2012:24).

"Efektivitas

pemanfaatan

sumber daya, sarana dan prasarana dalam jumlah tertentu yang secara sadar ditetapkan sebelumnya untuk menghasilkan sejumlah pekerjaan tepat pada waktunya" (Abdurahmat, 2011:92).

Efektifitas adalah seberapa besar tingkat kelekatan output yang dicapai dengan output yang diharapkan dari sejumlah input (Prastyo Budi, 2011: 46).

Menurut Kamus Besar Bahasa Indonesia, (2015:61) efektif mempunyai arti efek, pengaruh, akibat atau dapat membawa hasil. Efektivitas diartikan sebagai tingkat keberhasilan yang dapat dicapai dari suatu usaha sesuai dengan tujuan hendak dicapai.

Menurut Schemerhon John, (2014:35) "Efektivitas adalah pencapaian target output yang diukur dengan cara membandingkan output anggaran atau seharusnya (OA) dengan output realisasi atau sesungguhnya (OS), jika (OS) > (OA) disebut efektif".

Efektivitas kerja berhubungan dengan pemanfaatan sumber daya manusia, baik individu dan kelompok, sarana dan prasarana untuk mencapai tujuan organisasi. Oleh sebab itu hampir setiap organisasi selalu berusaha semaksimal mungkin mengupayakan dan memelihara karyawan, agar dapat melaksanakan fungsi dan tugas pokoknya dengan efektivitas kerja yang tinggi.

Dari pendapat-pendapat di atas, dapat disimpulkan bahwa efektivitas adalah suatu tingkat keberhasilan dalam mencapai tujuan tertentu dalam organisasi atau dapat dikatakan dengan hasil kerja. Lain halnya dengan efisien yang melihat perbandingan input dan output. Efisiensi dikaji dari segi jumlah sumber daya yang dipergunakan untuk menghasilkan suatu unit keluaran (Input output). Salah satu yang dapat mengukur pencapaian tujuan organisasi adalah efektivitas para individu atau anggotanya di dalam melaksanakan tugas-tugas pekerjaannya. 


\section{METODOLOGI PENELITIAN}

\section{Objek Penelitian}

Objek penelitian ini adalah

PT.

Karya Niaga berlokasi di Jalan Ikan Tongkol No. 74 Teluk Betung Bandar Lampung, sektor usahanya di bidang perdagangan lampu bermerk philips. Pengumpulan data dilakukan pada bulan Februari sampai Juli 2019.

\section{Metode Penelitian}

Adapun metode penelitian yang digunakan adalah ;

Analisis kualitatif, yaitu : metode pemecahan masalah berdasarkan data data perolehan dan mengulasnya secara pendekatan teori marketing dan manajemen berupa keterangan dan penjelasan.

Analisis kuantitatif, yaitu : menggunakan perhitungan statistik regresi linier sederhana untuk mengetahui besaran pengaruh promosi terhadap efektivitas kerja karyawan pada PT. Karya Niaga di Bandar Lampung.

\section{Metode Analisis}

\section{Analisis Kualitatif}

Dalam analisis dari data perolehan ini, penulis menggunakan pendekatan teori marketing bauran pemasaran dan manajemen sumber daya manusia mengenai promosi dan efektivitas kerja karyawan, hasilnya berupa keterangan dan penjelasan pokok permasalahan.

\section{Analisis Kuantitatif}

Data primer diperoleh dari penyebaran angket pertanyaan (kuesioner) mengenai promosi dan efektivitas kerja karyawan kepada responden, dianalisis secara kuantitatif menggunakan analisis regresi linier sederhana, yaitu :

$\mathrm{Y}=\mathrm{a}+\mathrm{bX}$

Keterangan

$\mathrm{Y}=$ Efektivitas kerja

$\mathrm{a}=$ Konstanta

$\mathrm{b}=$ Koefisien regresi sederhana

$\mathrm{X}=$ Anggaran Promosi

Dengan asumsi :

1. Harga dianggap tetap

2. Selera dianggap tetap

3. Teknologi

Sedangkan untuk melihat besarnya hubungan antara promosi dengan efektivitas kerja karyawan dilihat dari hasil penjualan digunakan fungsi korelasi, sebagai berikut :

$$
\begin{aligned}
& \mathrm{a}=\frac{\mathrm{n} \cdot \sum \mathrm{XY}-\sum \mathrm{X} \cdot \sum \mathrm{Y}}{\mathrm{n} \cdot \sum \mathrm{X}^{2}-\left(\sum \mathrm{X}\right)^{2}} \\
& \mathrm{~b}=\frac{\sum \mathrm{Y}-\mathrm{b} \cdot \Sigma \mathrm{X}}{\mathrm{n}}
\end{aligned}
$$

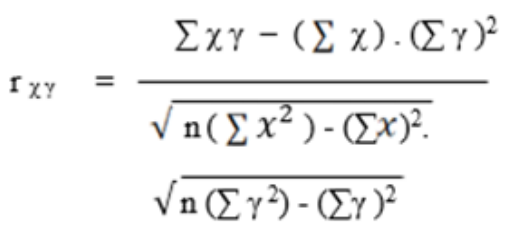

a. $\mathrm{r}=0$ atau mendekati 0 , maka korelasi $\mathrm{x}$ dan $\mathrm{y}$ lemah (tidak ada pengaruh promosi terhadap efektivitas kerja karyawan)

b. $\mathrm{r}=+1$ atau mendekati +1 , maka (ada pengaruh positif, promosi terhadap efektivitas kerja karyawan) 
c. $\mathrm{r}=-1$ atau mendekati -1 , maka (ada pengaruh kuat dan negatif promosi terhadap efektivitas kerja karyawan)

Sedangkan untuk melihat kadar persentase pengaruh promosi terhadap efektivitas kerja karyawan dilihat dari hasil penjualan produk lampu philips digunakan rumus ;

$\mathrm{KD}=(\mathrm{r}) 2 \times 100 \%$

Untuk menguji hipotesis, terlebih dahulu dicari nilai $t$ student

$$
\mathbf{t}=\frac{r \sqrt{N-2}}{\sqrt{1-r^{2}}}
$$

Membandingkan nilai t student dengan nilai t tabel pada taraf signifikan $95 \%$.

Ketentuan yang dipakai adalah :

a. Jika $\mathrm{t}$ hitung $\geq \mathrm{t}$ tabel pada taraf signifikan 95\% maka Ho ditolak, Ha diterima.

Berarti ada pengaruh promosi terhadap efektivitas kerja karyawan pada PT. Karya Niaga di Bandar Lampung.

b. Jika $\mathrm{t}$ hitung $\leq \mathrm{t}$ tabel pada taraf signifikan 95\%, maka Ho ditolak, Ha diterima.

Berarti tidak ada pengaruh promosi terhadap efektivitas kerja karyawan pada PT. Karya Niaga di Bandar Lampung.

\section{HASIL PENELITIAN DAN PEMBAHASAN}

\section{Hasil Penelitian}

PT. Karya Niaga di Bandar Lampung dalam menghadapi persaingan usaha lampu sejenisnya dengan harga relatif lebih murah, maka manajemen harus mengambil serangkaian kebijaksanaan di bidang pemasaran secara tepat, sangat ditentukan oleh variabel yang terdapat dalam bauran pemasaran, yaitu : produk, harga, promosi dan distribusi.

Salah satu bauran pemasaran tersebut adalah menaikkan anggaran promosi setiap tahunnya, agar karyawan dalam memasarkan produk lampu philips kepada konsumen melalui agen dan toko-toko menjadi efektif, karena telah diinformasikan mengenai kualitas, jaminan mutu dan pelayanannya, sehingga diharapkan dapat meningkatkan hasil penjualan.

Kegiatan promosi merupakan salah salah satu kegiatan yang sifatnya memperkenalkan produk, membujuk dan meyakinkan serta meningkatkan manfaat dari produk yang ditawarkan dengan maksud untuk menerik minat konsumen agar membeli produk yang bersangkutan.

Tujuan dari kegiatan promosi yang dilaksanakan PT. Karya Niaga di Bandar Lampung selain meningkatkan penerimaan dari hasil penjualan, memantapkan dan meningkatkan jumlah pembeli dan memberitahukan pasar yang akan dituju tentang penawaran philips.

Untuklebihjelasnya tergambarkan secara global anggaran promosi yang telah dikeluarkan oleh perusahaan selama 5 (lima) tahun sebagai berikut :

Tabel 1. Anggaran Promosi Lampu Philips PT. Karya Niaga di Bandar Lampung, Tahun 2014-2018 (jutaan rupiah). 


\begin{tabular}{|l|l|l|l|l|l|}
\hline $\begin{array}{c}\text { Peri- } \\
\text { ode }\end{array}$ & 2014 & 2015 & 2016 & 2017 & 2018 \\
\hline Sem I & 15,4 & 18,5 & 2,2 & 6,6 & 29,1 \\
\hline $\begin{array}{l}\text { Sem } \\
\text { II }\end{array}$ & 16,9 & 20,3 & 24,4 & 27,1 & 29,6 \\
\hline Total & 32,3 & 38,8 & 46,6 & 53,7 & 58,7 \\
\hline
\end{tabular}

Sumber : PT. Karya Niaga di Bandar Lampung, Tahun 2019

PT. Karya Niaga di Bandar Lampung selalu berusaha semaksimal mungkin, agar dalam melaksanakan tugas dan pokok memasarkan produk lampu merk philips kepada konsumen terlaksana dengan efektivitas yang baik. Salah satu faktor yang mempengaruhi efektivitas kerja tersebut adalah manusia sebagai pelaksana tingkat keberhasilan yang dapat dicapai dari suatu usaha sesuai dengan tujuan hendak dicapai.

Berikut ini gambaran secara global hasil penjualan produk lampu philips yang dilaksanakan oleh PT. Karya Niaga di Bandar Lampung selama 5 (lima) tahun sebagai berikut :

\section{Tabel 2. Hasil penjualan lampu} philips PT. Karya Niaga di Bandar Lampung, Tahun 2014-2018 (dalam jutaan rupiah).

\begin{tabular}{|l|l|l|l|l|l|}
\hline $\begin{array}{c}\text { Peri- } \\
\text { ode }\end{array}$ & 2014 & 2015 & 2016 & 2017 & 2018 \\
\hline $\begin{array}{l}\text { Sem } \\
\text { I }\end{array}$ & 300,5 & 360,6 & 432,5 & 520,0 & 600,0 \\
\hline $\begin{array}{l}\text { Sem } \\
\text { II }\end{array}$ & 330,6 & 410,1 & 490,5 & 570,0 & 625,2 \\
\hline Total & 631,1 & 770,7 & 923,0 & $1.090,0$ & $1.225,2$ \\
\hline
\end{tabular}

Sumber : PT. Karya Niaga di Bandar Lampung, Tahun 2019

\section{Pembahasan}

Dalam hal ini penulis menganalisis berdasarkan data perolehan selama 5 tahun mengenai anggaran promosi sebagai variabel $(\mathrm{x})$ terhadap efektivitas kerja karyawan (Y) dalam memasarkan produk lampu philips, dilihat dari hasil penjualan.

Untuk menganalisis data tersebut dibagi dalam 3 (tiga) bagian, yaitu :

1. Analisis Regresi

Untuk memperkirakan besarnya pengaruh secara kuantitatif dari variabel $x$ terhadap variabel y,

Selanjutnya data dari masing-masing variabel direkapitulasikan ke dalam tabel 3 menggunakan metode least square sebagai berikut :

Tabel 3. Hasil perhitungan regersi linier sederhana dengan metode least square (dalam jutaan rupiah).

\begin{tabular}{ccrrr}
\hline $\mathrm{X}$ & $\mathrm{Y}$ & \multicolumn{1}{c}{$\mathrm{XY}$} & \multicolumn{1}{c}{$\mathrm{X}^{2}$} & \multicolumn{1}{c}{$\mathrm{Y}^{2}$} \\
\hline 15,4 & 300,0 & $4.627,70$ & 37,16 & $90.300,25$ \\
16,9 & 330,6 & $5.587,14$ & 285,61 & $109.296,36$ \\
18,5 & 360,6 & $6,671,10$ & 342,25 & $130.032,36$ \\
20,3 & 410,1 & $8.325,03$ & 412,09 & $168.182,01$ \\
22,2 & 432,5 & $9.610,50$ & 492,84 & $187.056,25$ \\
24,4 & 490,5 & $11.968,20$ & 595,36 & $140.590,25$ \\
26,6 & 520,0 & $13.832,00$ & 707,56 & $270.400,00$ \\
27,1 & 570,0 & $15.447,00$ & 734,41 & $324.900,00$ \\
29,1 & 600,0 & $17.460,00$ & 846,81 & $360.000,00$ \\
29,5 & 625,2 & $18.443,40$ & 870,25 & $390.875,04$ \\
\hline 230,0 & $4.640,0$ & $111.963,07$ & $5.524,34$ & $2.271 .632,52$ \\
\hline
\end{tabular}

Sumber : Hasil penelitian, Tahun 2019 


$$
\begin{aligned}
& (\Sigma \mathrm{X})^{2}=52.900 \\
& (\Sigma Y)^{2}=21.529 .600 \\
& \begin{aligned}
\mathrm{b} & =\frac{\mathrm{n} \cdot \Sigma \mathrm{XY}-\Sigma \mathrm{X} \cdot \Sigma \mathrm{Y}}{\mathrm{n} \cdot \Sigma \mathrm{X}^{2}-(\Sigma \mathrm{X})^{2}} \\
& =10 \cdot(111 \cdot 963,07)-(230) \cdot(4 \cdot 640)
\end{aligned} \\
& 10 \quad(5.524,34)-52.900 \\
& =\quad 1.119 .630,7-1.067 .200 \\
& 55.243,4-52.900 \\
& =\frac{52.430,7}{2.343,4} \\
& =22,3 \\
& a=\frac{\sum Y-b \cdot \Sigma X}{n} \\
& \mathrm{a}=\frac{4 \cdot 460-(22,37) \cdot(230)}{10} \\
& \mathrm{a}=\frac{4.460-5.145,1}{10} \\
& \mathrm{a}=\frac{-505,51}{10} \\
& \mathrm{a}=-50,51
\end{aligned}
$$

Selanjutnya hasil perhitungan tersebut di atas, diperoleh persamaan

$$
\mathrm{Y}=-50,51+22,37
$$

Berarti, $\mathrm{r}=+1$ atau mendekati +1 , mengartikan bahwa bila anggaran promosi dinaikan atau dikurangi sebesar 1\%, maka nilai efektivitas kerja karyawan akan bertambah atau berkurang 22,37\%, sedangkan bila anggran promosi tetap, maka nilai efektivitas kerja karyawan akan berkurang sebesar Rp. 50.510.000,-. Dengan demikian ada pengaruh promosi yang positif, terhadap efektivitas kerja karyawan pada PT. Karya Niaga di
Bandar Lampung;

$$
\begin{aligned}
\mathrm{r}_{\chi \gamma} & =\frac{\sum \chi \gamma-\left(\sum \chi\right) \cdot\left(\sum \gamma\right)^{2}}{\sqrt{\mathrm{n}\left(\sum x^{2}\right)-\left(\sum x\right)^{2}} \cdot} \\
\mathrm{r} & =\frac{\sqrt{\mathrm{n}\left(\sum \gamma^{2}\right)-\left(\sum \gamma\right)^{2}}}{\sqrt{2.342,4} \cdot \sqrt{1.186 .725,2}} \\
\mathrm{r} & =\frac{52 \cdot 430,7}{(48,40) \cdot(1.089,36} \\
\mathrm{r} & =\frac{52.430,7}{52.725,0} \\
\mathrm{r} & =0,99
\end{aligned}
$$

Berarti bahwa promosi berpengaruh positif terhadap efektivitas kerja karyawan dalam melakukan penjualan, bila anggaran promosi naik, maka efektivitas kerja karyawan pada PT. Karya Niaga di Bandar Lampung juga naik, jika dilihat dari hasil penjualan.

Koefisien Determinasi

$$
\begin{aligned}
\mathrm{KD} & =\mathrm{r}^{2} \times 100 \% \\
& =(0,99)^{2} \times 100 \% \\
& =0,9801 \times 100 \% \\
& =98,01
\end{aligned}
$$

Berarti bahwa efektivitas kerja karyawan pada PT. Karya Niaga di Bandar Lampung dipengaruhi promosi sebesar $98,01 \%$ dan sisanya $1,99 \%$ oleh faktor lainnya. 


\section{SIMPULAN DAN SARAN}

\section{Simpulan}

Berdasarkan hasil penelitian dan pembahasan yang telah dilakukan, maka penulis menyimpulkan antara lain :

1. Kegiatanpromosiyangdilakukanoleh PT. Karya Niaga di Bandar Lampung mampu mengatasi persaingan pasar, hal ini terbukti setelah dinaikannya anggaran promosi berpengaruh terhadap efektivitas kerja karyawan, hasil penjualan produk lampu philips juga naik.

2. Persamaan regresi, yaitu: $\mathrm{Y}=-50,51$ $+22,37$, mengartikan bahwa bila anggaran ditambah atau diturunkan sebesar $1 \%$, maka nilai efektivitas kerja karyawan dari hasil penjualan akan bertambah atau berkurang sebesar 22,37 \%, sedangkan bila anggaran promosi yang ditambah itu tetap, maka nilai keuntungan yang diperoleh akan berkurang sebesar $\mathrm{Rp}$ 50.510.000,-.

3. Koefisien korelasi, yaitu 0,99 mengartikan bahwa anggaran promosi berpengaruh positif terhadap efektivitas kerja karyawan pada PT. Karya Niaga di Bandar Lampung. Selain itu besarnya pengaruh promosi terhadap efektivitas kerja karyawan adalah $\quad 98,01 \quad \%$ sisanya $\quad 1,99 \%$ dipengaruhi oleh faktor lainnya yang tidak dibahas dalam penelitian ini.

\section{Saran}

Sedikit saran yang akan disampaikan penulis sebagai berikut :

1. PT. Karya Niaga di Bandar Lampung agar dapat mencapai hasil yang maksimal dari hasil penjualan, maka sebaiknya perusahaan meningkatkan kegiatan promosi, sehingga mendorong efektivitas pembelian konsumen dan pedagang.

2. PT. Karya Niaga di Bandar Lampung sebaiknya menitik beratkan pada keputusan pembelian mengenai kualitas barang dan jaminan pelayanannya dengan harga terjangkau sehingga perusahaan lampu philips menjadikan konsumen loyalitas.

\section{DAFTAR PUSTAKA}

Arikunto Suharsimi, 2011. Prosedur Penelitian. Penerbit Bina Aksara. Jakarta.

DH Basu Swastha, 2014. Manajemen Pemasaran. Mandar Maju. Bandung.

John Schemerhon, 2014. Manajemen

Pemasaran. Penerbit Erlangga. Jakarta.

Kamus Besar Bahasa Indonesia, 2015. Penerbit Ghalia Indonesia. Jakarta.

Kotler Philips, 2012. Manajemen

Pemasaran. Penerbit. PT.

Erlangga. Jakarta.

Prawiraatmaja Rahman, 2014.

Manajemen Pemasaran. BPFE UGM.Yokyakarta.

Subagyo, 2011. Teori dan Aplikasi.

Radja Grafindo Persada. Jakarta.

Sudjana, 2012. Teori dan Praktek

Penelitian. Rineka Cipta. Jakarta

Supranto J, 2012. Metodologi Penelitian dan Riset. PT. Ghalia Indonesia. Jakarta. 